\title{
KARAKTERISTIK FISIK LIPSTIK SARI KULIT BUAH NAGA MERAH (Hylocereus costaricensis) DENGAN VARIASI PERBANDINGAN KONSENTRASI CARNAUBA WAX DAN BEESWAX
}

\author{
Dewi Andini Kunti Mulangsri ${ }^{1^{*}}$, Mimiek Murrukmihadi ${ }^{2}$, Eni Muaniqoh ${ }^{1}$ \\ ${ }^{1}$ Fakultas Farmasi, Universitas Wahid Hasyim \\ Jl. Menoreh Tengah X/22, Sampangan, Semarang 50236. \\ ${ }^{2}$ Fakultas Farmasi, Universitas Gadjah Mada \\ Jl. Bulaksumur, Kec. Depok, Kabupaten Sleman, Yogyakarta 55281 \\ Email: andini@unwahas.ac.id
}

\begin{abstract}
Abstrak
Kulit buah naga merah sebagai limbah yang dapat dimanfaatkan zat warna merah antosianin sebagai pewarna alami sediaan lipstik. Pewarna alami memiliki keunggulan yaitu lebih aman dan adanya aktivitas antioksidannya. Lisptik yang baik ditinjau dari karakteristik fisiknya yang dipengaruhi oleh basis lisptik yaitu lilinya berupa Carnauba wax dan Beeswax. Penelitian ini bertujuan untuk mengetahui karakteristik fisik lipstik sari kulit buah naga merah dengan variasi perbandingan Carnauba wax dan Beeswax.

Sari kulit buah naga merah diperoleh dengan proses penyaringan hasil blender kulit buah naga merah yang rendemen sarinya sebesar $81.78 \%$. Dirancang lima formula lipstik dengan konsentrasi sari kulit buah naga merah sebesar 25\% dan perbandingan antara Carnauba wax: Beeswax pada F1 (1:1), F2 (1:2), F3 (1:3), F4 (2:1) dan F5 (3:1). Metode pembuatan lipstik yang digunakan adalah metode peleburan dan pencampuran sari kulit buah naga merah dalam suhu yang tidak terlalu panas. Lipstik yang dihasilkan diujikan karakteristik fisik dan daya olesnya.

Hasil menunjukkan bahwa lipstik sari kulit buah naga merah memiliki warna merah muda, homogen dengan pH lipstik 5,1. Hasil analisis statistik menunjukkan bahwa semakin meningkatnya konsentrasi Beeswax dapat menurunkan titik lebur dan kekerasannya namun sebaliknya semakin meningkatnya konsentrasi Carnauba wax akan meningkatkan pula titik lebur dan kekerasannya. Dari kelima formula masih memenuhi karkateristik fisik lipstik yang dapat diterima namun daya olesnya belum cukup baik karena ketika dioleskan warna belum intensif.
\end{abstract}

Kata kunci: Antosianin, Beeswax, Carnauba wax, Lipstik

\section{PENDAHULUAN}

Kulit buah naga merah (Hylocereus costaricensis peel) ini ternyata memiliki kandungan antosianin yang cukup tinggi dalam pelarut air sebesar $62,68 \%$ (Simanjuntak dkk., 2014). Antosianin memberikan warna merah yang terkandung di dalam kulit buah naga merah berjenis sianidin 3-rammosil glukosida 5-glukosida (Le Bellec et al., 2006). Antosianin dapat digunakan sebagai pewarna alami yang relatif lebih aman dibandingkan dengan pewarna sintetik. Selain itu antosianin dalam kulit buah naga merah memiliki aktivitas antioksidan yang kuat dengan nilai $\mathrm{IC}_{50}$ sebesar $73,2772 \mathrm{mg} / \mathrm{L}$ (Putri dkk., 2015). Walaupun aktivitas antioksidan dari lipstik buah naga merah memiliki aktivitas yang lemah dengan nilai $\mathrm{IC}_{50}$ sebesar $1215.72 \mu \mathrm{g} / \mathrm{ml}$ (Nurhaida dkk., 2017).

Lipstik yang baik adalah lipstik yang memiliki karakteristik menarik dan dapat diterima konsumen dalam hal tekstur dan antioksidan. Tekstur, titik lebur dan kekerasan lipstik dapat dipengaruhi oleh perbandingan komposisi dari basis di dalam formula lipstik (Kamairudin et al., 2014). Basis yang dapat mempengaruhi karakteristik dari lipstik salah satunya basis lilin seperti Carnauba wax dan Beeswax. Beeswax merupakan malam yang bersifat inert, umum digunakan dalam sediaan lipstik, bersifat emollient, memiliki titik lebur 62$64^{\circ} \mathrm{C}$ (Depkes RI., 1986). Namun Beeswax memiliki kelemahan yaitu dalam konsentrasi tinggi menyebabkan lipstik yang kasar dan kusam (Jellineck, 1970). Sedangkan Carnauba wax memiliki titik lebur yang tinggi $80-88^{\circ} \mathrm{C}$ dan dapat membuat tekstur lebih creamy dan shiny (DepKes RI, 1979). Masing-masing basis lilin tersebut dapat saling melengkapi sehingga dapat dikombinasikan dengan perbandingan konsentrasi agar menghasilkan lipstik yang baik.

\section{METODOLOGI}

Bahan dan Alat Penelitian 
Bahan kulit buah naga merah diperoleh dari Desa Wonosari RT II RW VII Patebon Kendal. Bahan dengan kualitas farmasetis berupa HCL 0,1 \%; Lanolin; Propil paraben; metil paraben; Tween 80, Minyak Jarak, Carnauba wax dan Beeswax.

Alat penelitian yang digunakan antara lain neraca digital, glassware, blender, kain flannel, batang pengaduk kaca, mortir, stamfer, cawan porselen, sendok tanduk, alat pencetak suppositoria, sudip dan alat pendukung lainnya

\section{Jalan Penelitian}

1) Determinasi Tanaman

Determinasi tanaman dilakukan di laboratorium FMIPA Universitas Diponegoro (UNDIP) dengan membandingkan sampel tanaman dengan literatur. Determinasi tanaman bertujuan untuk meyakinkan dan memastikan bahwa benar tanaman tersebut adlaah tanaman yang digunakan untuk penelitian.

2) Pembuatan Sari Kulit Buah Naga Merah

Kulit buah naga merah yang telah terkupas dicuci kemudian diblender. Sari kulit buah naga merah diperoleh dengan menyaring dan memeras hasil blender kulit buah naga merah.sari kuliit buah naga merah ditambahkan HCL 0,1 \% sampai pH 5,0 untuk mencegah terjadinya diskolorisasi (Jeszka, 2007).

3) Karakteristik Sari Kulit Buah Naga

Pengujian organoleptis meliputi pengujian warna, bau dan rasa. Selain itu pengujian $\mathrm{pH}$ sari kulit buah naga sebelum

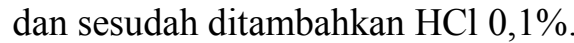

4) Pembuatan Lipstik Kulit Buah Naga Merah

Formula modifikasi lipstik dengan kombinasi basis Carnauba wax dan Besswax disajikan pada Tabel I.

Tabel I. Formula Lipstik Sari Kulit Buah Naga Merah

\begin{tabular}{cccccc}
\hline \multirow{2}{*}{ Komposisi } & \multicolumn{7}{c}{ Sediaan ( \%) } \\
\cline { 2 - 6 } & F1 & F2 & F3 & F4 & F5 \\
\hline kulit buah naga merah & 25 & 25 & 25 & 25 & 25 \\
\hline Carnauba wax & 6,5 & 4,33 & 3,25 & 8,66 & 9,75 \\
\hline Bees wax & 6,5 & 8,66 & 9,75 & 4,33 & 3,25 \\
\hline Minyak jarak & 33,3 & 33,3 & 33,3 & 33,3 & 33,3 \\
\hline Setil alkohol & 10 & 10 & 10 & 10 & 10 \\
\hline Lanolin & 12 & 12 & 12 & 12 & 12 \\
\hline Metil paraben & 0,1 & 0,1 & 0,1 & 0,1 & 0,1 \\
\hline Propil paraben & 0,1 & 0,1 & 0,1 & 0,1 & 0,1 \\
\hline Tween 80 & 6,5 & 6,5 & 6,5 & 6,5 & 6,5 \\
\hline
\end{tabular}

Metode pembuatan lipstik sari kulit buah naga menggunakan metode peleburan. Prosedur pembuatan lipstik sari kulit buah naga merah disajikan pada Gambar 1.

5) Pemeriksaan Sifat Fisik Lipstik

a) Pemeriksaan organoleptis

Pemeriksaan organoleptis berupa warna, bau, rasa dan kilau terhadap sediaan lipstik sari kulit buah naga merah.

b) Pemeriksaan homogenitas

Pemeriksaan ini dilakukan dengan cara mengoleskan sediaan lipstik pada bahan yang permukaannya licin dan putih (Mitsui, 1997).

Pemeriksaan homogenitas dan kestabilan warna dapat dilakukan juga dengan cara memotong lipstik secara membujur dan diamati terhadap bintik-bintik pewarna atau tidak (Vishwakarma et al., 2011).

c) Pemeriksaan $\mathrm{pH}$ sediaan lipstik

Pemeriksaan ini menggunakan alat $\mathrm{pH}$-meter yang telah dikalbrasi dengan larutan dapar standar netral pH 7,0 dan larutan dapar asam pH 4,0. Sampel lipstik dibuat konsentrasi 1\% yaitu 1 gram dalam $100 \mathrm{ml}$ aquadest. Larutan ini kemudian dicek $\mathrm{pH}$ dengan $\mathrm{pH}$-meter (Rawlins, 2003).

d) Pemeriksaan titik lebur

Pemeriksaan ini dilakukan dengan cara Masing-masing sediaan dimasukkan dalam tabung reaksi kemudian dilelehkan ke dalam waterbath atau oven dengan melihat kenaikkan suhu dimana sediaan lipstik melebur pada saat pertama kali (Ditjen POM, 1985).

e) Pemeriksaan kekerasan (Breaking point)

Pemeriksaan ini dilakukan dengan cara Sediaan lipstik diletakkan pada posisi horizontal dengan jarak kira-kira $1 / 2$ dari tepi sediaan lipstick. Kemudian berat beban ditambahkan secara berangsur-angsur dengan nilai yang spesifik $50 \mathrm{~g}$ setiap interval waktu 
30 detik. Berat dimana lipstik patah merupakan nilai Breaking point (Lauffer, 1972).

f) Uji daya oles sediaan lipstik

Uji oleh dilakukan secara visual dengan cara mengoleskan lipstik pada kulit tangan kemudian mengamati banyaknya warna yang menempel pada tekanan tertentu seperti biasanya kita menggunakan lipstik. Pemeriksaan dilakukan terhadap masingmasing sediaan yang dibuat dan dioleskan pada kulit tangan dengan 5 kali pengolesan (Keithler, 1956).

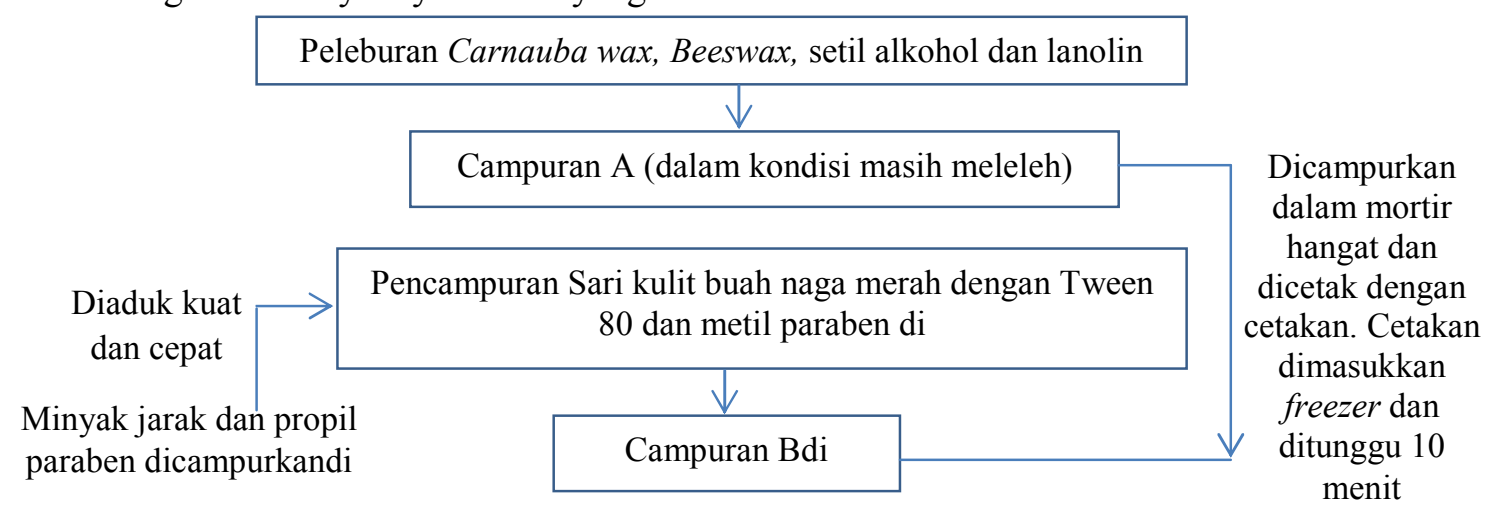

Gambar 1.Prosedur Pembuatan Lipstik Sari Kulit Buah Naga Merah

a. Analisa Data

Analisa data dilakukan dengan dua cara yaitu yang pertaman pendekatan deskriptif untuk data dari uji organoleptik, homogenitas, $\mathrm{pH}$ dan daya oles. Pendektan kedua yaitu pendektan statistik untuk uji kekerasan dengan statistik Anova satu jalan (taraf kepercayaan 95\%) dilanjutkan uji Tuekey dan data uji titik lebur dianalisis dengan uji Kruskalwallis dilanjutkan dengan Mann Whitney.

\section{HASIL DAN PEMBAHASAN}

a. Determinasi Tanaman

Hasil determinasi menyatakan bahwa buah naga merah yang digunakan dalam penelitian ini adalah benar buah naga merah dengan nama latin Hylocereus costaricensis.

\section{b. Pembuatan Sari Kulit Buah Naga} Merah

Rendemen sari kulit buah naga merah yang diperoleh sebesar $81,78 \%$ dari berat kulit buah naga merah 483 gram.

\section{c. Karakteristik Sari Kulit Buah Naga Merah}

Karakteristik sari kuli buah naga merah berupa cairan berwarna merah pekat dengan bau khas buah naga namun tidak berasa.

d. Pembuatan Lipstik Sari Kulit Buah Naga Merah

Di dalam formula lipstik lebih didominasi bahan-bahan yang berminyak seperti minyak jarak dan wax. Sedangkan bahan pewarna alami yang digunakan bersifat polar karena berupa sari. Sehingga perlu penambahan bahan surfaktan agar dapat mencampurkan kedua bahan yang berbeda kepolaran ini yaitu Tween 80 . Hasil orientasi kadar Tween yang digunakan adalah $6,5 \%$. Dengan adanya Tween 80 dapat menghomogenkan warna dari sari kulit buah naga merah dengan basis yang berminyak.

Metode pembuatan yang digunakan adalah metode peleburan, yang mana basis lilin dileburkan bersama-sama. Kemudian dicampurkan dengan bagian pewarna alaminya. Yang perlu diperhatikan adalah sifat dari antosianin sebagai sumber perwarna alami yang memiliki ketidakstabilan terhadap suhu. Pada suhu $50^{\circ} \mathrm{C}$, pigmen antosianin yang tersari cukup banyak dibandingkan ketika suhu $60^{\circ} \mathrm{C}$ dan $70^{\circ} \mathrm{C}$ yang dapat diartikan juga bahwa pigmen antosianin dapat bertahan pada suhu $50^{\circ} \mathrm{C}$ (Kwartiningsih dkk., 2016). Oleh sebab itu dalam pencampurannya dengan leburan lilin tidak melebihi suhu $50^{\circ} \mathrm{C}$.

e. Pemeriksaan Fisik Sediaan Lipstik

1) Organoleptis lipstik sari kulit buah naga merah dari kelima formula disajikan pada Tabel II. 
Tabel II. Hasil Pengujian Organoleptis Lisptik Sari Kulit Buah Naga Merah

\begin{tabular}{cllll}
\hline \multirow{2}{*}{ Formula } & \multicolumn{4}{c}{ Organoleptis } \\
\cline { 2 - 5 } & Warna & Bau & Rasa & Kilau \\
\hline 1 & Merah muda & Khas lilin & Tidak berasa & Kurang berkilau \\
\hline 2 & Merah muda & Khas lilin & Tidak berasa & Kurang berkilau \\
\hline 3 & Merah muda & Khas lilin & Tidak berasa & Kurang berkilau \\
\hline 4 & Merah muda & Khas lilin & Tidak berasa & Kurang berkilau \\
\hline 5 & Merah muda & Khas lilin & Tidak berasa & Kurang berkilau \\
\hline
\end{tabular}

Warna lipstik yang dihasilkan adalah merah muda. Warna merah muda ini berasal dari warna sari kulit buah naga merah, karena bercampur dengan bahan-bahan lainnya maka warna merah pekat dari warna sari sebelumnya menjadi warna merah muda. Dari hasil organoleptis ini maka warna dari pigmen antosianin dalam sari kulit buah naga merah dapat digunakan sebagai pewarna alami. Kadar sari kulit buah naga merah dalam formula digunakan sebesar $25 \%$ yang berdasarkan penelitian Lutfia (2011), pada sari umbi bit konsentrasi yang baik adalah $25 \%$. Dengan kadar tersebut sudah mampu memberikan warna yang baik. Namun dari kelima formula tidak memberikan tambahan parfum sehingga bau khas lipstik yaitu bau lilin dari basisnya. Dari kelima formula dengan kadar zat warna alami yang sama juga memiliki warna akhir lipstik yang sama pula. Gambar 2 di bawah ini menunjukkan bentuk lipstik dari kelima formula.

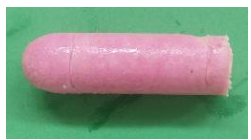

F1

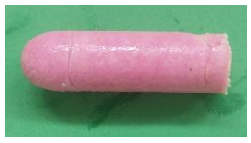

F2

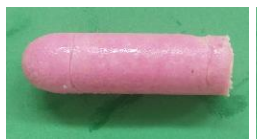

F3

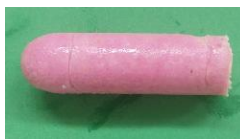

F4

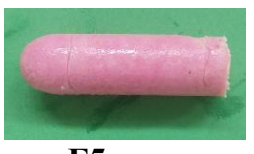

F5

Gambar 2. Lipstik sari Kulit Buah Naga Merah

2) Homogenitas lipstik sari kulit buah naga merah

Hasil menunjukkan bahwa lipstik sari kulit buah naga merah telah homogen yang ditandai dengan tidak adanya butir-butir kasar saat lipstik dioleskan pada objectglass. Adanya Tween 80 di dalam formula dapat membantu menghomogenkan zat warna di dalam sari kulit buah naga merah. Dan dari kelima formula, lipstik yang dihasilkan homogen.

3) Pemeriksaan $\mathrm{pH}$ lipstik sari kulit buah naga merah

Hasil menunjukkan bahwa $\mathrm{pH}$ lipstik sari kulit buah naga merah memiliki $\mathrm{pH} \mathrm{5,1} \mathrm{pada}$ kelima formula. Hal ini menunjukkan bahwa adanya variasi kombinasi basis lilin tidak mempengaruhi $\mathrm{pH}$ lipstik. Nilai $\mathrm{pH} 5,1$ menunjukkan bahwa lipstik sari kulit buah naga merah tidak akan mengiritiasi bibir karena masih berada pada kisaran $\mathrm{pH}$ bibir yaitu 4,5-7 (Wasitaadmadja, 1997).

4) Titik lebur lipstik sari kulit buah naga merah

Hasil pengujian ini menunjukkan bahwa titik lebur dari kelima formula masih memenuhi kriteria yang diinginkan yaitu diatas $50^{\circ} \mathrm{C}$. Pada Tabel III ini disajikan nilai titik lebur dari kelima formula.

Tabel III. Hasil Uji Titik Lebur Sediaan Lipstik Sari Kulit Buah Naga

\begin{tabular}{cc}
\hline Formula & Titik lebur \pm SD \\
\hline 1 & $64 \pm 0.577$ \\
\hline 2 & $63 \pm 0.577$ \\
\hline 3 & $61 \pm 1.000$ \\
\hline 4 & $66 \pm 1.155$ \\
\hline 5 & $67 \pm 0.707$ \\
\hline
\end{tabular}

Hasil analisis dengan statistik menggambarkan bahwa adanya variasi perbandingan dari basis lilin dapat mempengaruhi titik lebur. Semakin tinggi konsentrasi dari Carnauba wax dibandingkan konsentrasi Beeswax maka akan semakin tinggi pula titik leburnya. Hal 
ini terlihat pada formula 3,4 dan 5 ada perbedaan yang bermakna. Hasil statistik ini juga menggambarkan bahwa Beeswax juga dapat mempengaruhi titik lebur, namun kebalikannya yaitu titik leburnya semakin rendah jika dibandingkan dengan konsentrasi Carnauba wax lebih tinggi. Jadi benar jika Beeswax dapat melunakkan sediaan lipstik. Kelima formula tersebut memiliki ketahanan dalam penyimpanan di suhu ruang yang artinya tidak akan cepat meleleh.

5) Kekerasan lipstik sari kulit buah naga merah

Hasil pengujian ini menunjukkan bahwa variasi perbandingan dari kombinasi Carnauba wax dan Beeswax dapat mempengaruhi kekerasan lipstik. Hasil pengujiaan ini disajikan pada Tabel IV di bawah ini.

Tabel IV. Hasil kekerasan lipstik sari kulit buah naga (Hylocereus costaricensis)

\begin{tabular}{cc}
\hline Formula & Kekerasan \pm SD \\
\hline 1 & $550 \pm 50,000$ \\
\hline 2 & $450 \pm 50,000$ \\
\hline 3 & $400 \pm 50,000$ \\
\hline 4 & $600 \pm 50,000$ \\
\hline 5 & $700 \pm 50,000$ \\
\hline
\end{tabular}

Dengan konsentrasi Carnauba wax yang semakin tinggi pada formula lima maka akan menghasilkan lipstik dengan kekerasan yang lebih keras dibandingkan dengan keempat formula lainnya. Hal ini menunjukkan bahwa Carnauba wax akan mempengaruhi peningkatan kekerasan lipstik dibandingkan Beeswax yang akan mengurangi kekerasan lipstik. Kelima formula lipstik memiliki kekerasan yang dapat diterima, sehingga kelima formula lipstik ini memiliki daya tahan dalam pengemasan, distribusi, penyimpanan dan penggunaan.

\section{KESIMPULAN}

Sediaan lipstik sari kulit buah naga merah yang mengandung $25 \%$ sari kulit buah naga merah memiliki karaktersitik fisik yang masih dapat diterima dari kelima formula walaupun daya oles dari kelima formula tersebut belum cukup baik. Kombinasi Carnauba wax dan Beeswax dapat mempengaruhi titik lebur dan kekerasan lipstik.

\section{DAFTAR PUSTAKA}

Depkes RI.,1986, Sediaan galenik, Depatemen Kesehatan Republik Indonesia, Jakarta,10-14.

Depkes RI., 1979, Farmakope Indonesia, Edisi III, Departemen Kesehatan Republik Indonesia, Jakarta. 8, 65, 271,504 .
6) Daya oles lipstik sari kulit buah naga merah

Sediaan lipstik yang memiliki daya oles yang baik jika dioleskan di kulit tangan dapat memberikan warna yang intensif dan merata. Hasil dari pengujian ini menunjukkan bahwa kelima formula lipstik belum memiliki daya oles yang baik karena ketika dioleskan warna kurang intensif. Hal ini dapat disebabkan salah satunya karena konsentrasi dari sari kulit buah naga merah kurang tinggi, sehingga warna kurang intensif walaupun ketika dioleskan sudah homogen.

Ditjen POM. 1985, Formularium Kosmetika Indonesia. Jakarta: Departemen Kesehatan RI. 83, 85, 195-197.

Jellineck, S.,1970, Formulation and Function of cosmetics, 16, JohnWiley and Sons,Inc.,USA.428-433.

Jeszka, J., W. 2007, Food Colorants, dalam Sikorski, Z. E. (ED). Chemical and functional Pro[erties of Food Component. CRC Press LLC, New York. 265-268.

Kamairudin, N., Abd Gani, S.S., Masoumi, H.R.F., and Hashim, P., 2014, Optimization of Natural Lipstick Formulation Based on Pitaya (Hylocereus polyrhizus) Seed Oil Using D-Optimal Mixture Experimental Design, Molecules, $19: 16672-83$.

Keithler, W. R., 1956, Formulation of Cosmetic dan Cosmetic specialist, 
New York: Drug dan Cosmetic Industry, 153-155

Kwartiningsih, E., K.Prastika, A. dan Triana, D.L., 2016, Ekstraksi dan Uji Stabilitas Antosianin dari Kulit Buah Naga Super Merah (Hylocereus costaricensis), Prosiding Seminar Nasional Teknik Kimia "Kejuangan", 1-6.

Lauffer, P.G.I., 1972, Lipsticks, dalam Balsam, M.S.,Cosmetic Science and Technology, Second Edition, John Willey \& Sons Inc, USA, 367-377, 381-387.

Le Bellec, F., Vaillant, F., Imbert, E., 2006, Pitahaya (Hylocereus spp.): a new fruit crop, a market with a future. Fruits, 61(4): 237-250.

Lutfia, M., 2011, Pengaruh Peningkatan Konsentrasi Carnauba wax Terhadap Sifat Fisik Lipstik Sari Buah Bit ( Beta vulgaris L.), Skripsi, Universitas Muhammadiyah , Jakarta.

Mitsui, T. 1997, New Cosmetic Science. Amsterdam: Elsveir Science.3, 13, 121, 386.
Nurhaida A., Susilo, H., Sari, B.L., 2017, perpustakaan.fmipa.unpak.ac.id diakses tanggal 11 September 2017.

Putri, Ni K. M., Gunawan, I W.G., Suarsa, I W., 2015. Aktivitas Antioksidan Antosianin dalam Ekstrak Etanol Kulit Buah Naga Super Merah (Hylocereus costaricensis) dan analisis Kadar Totalnya, Jurnal Kimia, 9(2): 243-251.

Rawlins, E.A. 2003, Bentle's Textbook of Pharmaceutics. London, Bailierre Tindall. .22, 355.

Simanjuntak, L., Sinaga, C., dan Fatimah, 2014, Ekstraksi Pigmen Antosianin dari Kulit Buah Naga Merah (Hylocereus costaricensis), Jurnal Teknik Kimia USU, 1-5

Vishwakarma, B., Summet, D., Kushagra, D., and Hemant, J. 2011, Formulation and Evaluation Herbal Lipstik. International Jurnal of Drug Discovery Herbal Research 1.

Wasitaadmadja, S. M. 1997, Penuntun Ilmu Kosmetik Medik. Jakarta: Penerbit Universitas Indonesia. 3, 58-59, 62$63,111-112$. 